\title{
Potential Application of Cornelian Cherry Extract on Broiler Chickens: Growth, Expression of Antioxidant Biomarker and Glucose Transport Genes, and Oxidative Stability of Frozen Meat
}

\author{
Doaa Ibrahim ${ }^{1, *(\mathbb{D}}$, Amira Moustafa ${ }^{2} \mathbb{D}^{-}$, Aya Sh. Metwally ${ }^{3}$, Mohamed A. Nassan ${ }^{4} \mathbb{D}$, Karima Abdallah ${ }^{5}$, \\ Fatma Eldemery ${ }^{6}$, Vincenzo Tufarelli ${ }^{7}$ (D) , Vito Laudadio ${ }^{7}$ and Asmaa T. Y. Kishawy ${ }^{1, *(\mathbb{D}}$
}

check for

updates

Citation: Ibrahim, D.; Moustafa, A.; Metwally, A.S..; Nassan, M.A.; Abdallah, K.; Eldemery, F.; Tufarelli, V.; Laudadio, V.; Kishawy, A.T.Y. Potential Application of Cornelian Cherry Extract on Broiler Chickens: Growth, Expression of Antioxidant Biomarker and Glucose Transport Genes, and Oxidative Stability of Frozen Meat. Animals 2021, 11, 1038. https://doi.org/10.3390/ani11041038

Academic Editors: Woo Kyun Kim, Youssef A. Attia, Nesrein Hashem and Maria de Olivera

Received: 23 February 2021

Accepted: 5 April 2021

Published: 7 April 2021

Publisher's Note: MDPI stays neutral with regard to jurisdictional claims in published maps and institutional affiliations.

Copyright: (c) 2021 by the authors. Licensee MDPI, Basel, Switzerland. This article is an open access article distributed under the terms and conditions of the Creative Commons Attribution (CC BY) license (https:/ / creativecommons.org/licenses/by/ $4.0 /)$.
1 Department of Nutrition and Clinical Nutrition, Faculty of Veterinary Medicine, Zagazig University, Zagazig 44519, Egypt

2 Department of Physiology, Faculty of Veterinary Medicine, Zagazig University, Zagazig 44519, Egypt; amiramostafa@zu.edu.eg

3 Department of Pharmacology, Faculty of Veterinary Medicine, Aswan University, Aswan 81511, Egypt; ayashawky@aswu.edu.eg

4 Department of Clinical Laboratory Sciences, Turabah University College, Taif University, P.O. Box 11099, Taif 21944, Saudi Arabia; m.nassan@tu.edu.sa

5 Department of Food Control, Faculty of Veterinary Medicine, Zagazig University, Zagazig 44519, Egypt; karimaeissa1989@yahoo.com

6 Department of Hygiene and Zoonoses, Faculty of Veterinary Medicine, Mansoura University, Mansoura 35516, Egypt; Fatmaelbaz@mans.edu.eg

7 Department of DETO, Section of Veterinary Science and Animal Production, University of Bari, Strada Provinciale per Casamassima km 3, 70010 Valenzano, Italy; vincenzo.tufarelli@uniba.it (V.T.); vito.laudadio@uniba.it (V.L.)

* Correspondence: doibrahim@vet.zu.edu.eg (D.I.); No.dispair2000@gmail.com (A.T.Y.K.)

Simple Summary: Supplementation of the poultry diet with plant extracts rich in polyphenolic compounds could improve the performance of animals as well as the oxidative stability of their derived meat. The present study evaluated the efficacy of cornelian cherry extract (CCE) on the expression of genes controlling glucose transporters and different assays regulating the oxidative stability of frozen, stored meat over a long period of time (90 days of storage). The results indicated that the addition of $200 \mathrm{mg} / \mathrm{kg}$ of CCE to the diet could improve the growth rate and antioxidant status of broiler chickens and thus increase their productivity. Moreover, polyphenolic compounds rich in CCE can act as antioxidant agents to increase the shelf-life extension of frozen, stored poultry meat. Finally, supplementation with CCE could increase the total concentration of phenolic compounds in poultry meat offered to human consumers.

Abstract: The use of natural plant extracts in poultry feed could improve their productivity as well as the oxidative stability of stored derived meat. The roles of cornelian cherry extract (CCE) in growth, cecal microbes, and meat antioxidative markers of broiler chickens were evaluated. A total of 500 Ross 308 broiler chicks were fed diets supplemented with CCE (0, 50, 100, 200, $400 \mathrm{mg} / \mathrm{kg}$ of diet) for 38 days. The highest levels of weight gain and feed utilization were observed in a group fed $200 \mathrm{mg} / \mathrm{kg}$ of CCE. Maximum upregulation of glucose transporters-1 and 2 and sodium-dependent glucose transporter genes-were found in the group fed $200 \mathrm{mg} / \mathrm{kg}$ of CCE. Lactobacilli and Bifidobacterium colonization increased as the CCE levels increased. The greatest upregulation of antioxidant genes (glutathione peroxidase, catalase, and superoxide dismutase) in breast meat was observed in groups fed CCE (200 and $400 \mathrm{mg} / \mathrm{kg}$ ). Dietary CCE significantly delayed the lipid oxidation of breast meat compared with that of the control group. The total phenolic content, 2,2-Diphenyl-1-Picrihydrzyl (DPPH) radical scavenging activity and reducing power in meat improved with higher levels of CCE. Dietary CCE improved the growth, performance of broilers, and meat antioxidant stability after 90 days of storage. 
Keywords: cornelian cherry extract; glucose transporter; gene expression; oxidative biomarker; chicken

\section{Introduction}

The intention for the widespread use of phytonutrients in the poultry industry is ultimately associated with the growing discouragement of the use of antibiotics in feed. Recently, natural, active, plant-derived compounds have been gaining great importance, because of their ability to enhance poultry growth performance by improving nutrient digestibility, increasing the concentration of nutrient transporters, sustaining a healthy gut environment, and improving the quality of their products [1]. A phytogenic diet has also been reported to produce changes in the cell membrane permeability, resulting in a higher absorption rate of micronutrients from the small intestine [2]. Additionally, herbal and medicinal plant additives might have the capacity to control intestinal pathogenic bacteria and improve the beneficial intestinal microbiota [3-5] due to their antimicrobial, fungicidal, antiviral, anticoccidial, and antioxidant properties [6,7]. Furthermore, plant extracts that are rich in polyphenols can be effective for preserving meat and their products against oxidative deterioration, pathogen growth, and bacterial spoilage [8].

On the other hand, modern large-scale broiler production prompts stressful conditions such as high-stocking density, heat stress, immunological challenges, handling, feed quality, and transportation [9]. These stressors can enhance reactive oxygen species (ROS) production and interrupt the balance between the antioxidant defense systems and oxidation inside a bird's body, causing oxidative stress [10]. The harmful effect of oxidative stress can be reduced by the dietary inclusion of antioxidants [5]. The use of natural plant-derived compounds rich in polyphenolic compounds can improve the antioxidative status of the living birds and increase the oxidative stability of their derived meat [11].

Among these natural compounds is cornelian cherry (Cornus mas) extract (CCE), which is composed of several active compounds, including five anthocyanins: delphinidin 3-galactoside, cyanidin 3-rhamnosylgalactoside, cyanidin 3-galactoside, pelargonidin 3rhamnosylgalactoside, and pelargonidin 3-galactoside [12]. Ursolic acid is an important constituent of CCE [13-16] possessing antioxidant and antibacterial properties. Additionally, it contains vitamin C, trace minerals, organic acids, pectintriterpenoids, iridoids, pectins, and tannins that range within the safe standards levels of food [17-19]. It is rich in flavonoids such as quercetin 3-O-rhamnoside, quercetin 3-O-rutinoside, and quercetin 3-O-glucuronide [20] and phenolic compounds such as caffeic acid, caffeoylquinic acids, p-coumaric acid, and ellagic acid [21]. Furthermore, CCE has been shown to have antimicrobial [22] anti-inflammatory, and antioxidant activity [23] as well as a hypoglycemic effect [24]. Moreover, the high content of iridoids, such as cyclopentanopyran, found in CCE provides pharmacological properties such as antibiotic and anti-inflammatory effects [25].

Poultry meat is highly susceptible to quality deterioration by lipid oxidation during storage, leading to a decrease in nutritive value and the production of a high content of lipid oxidation products [26]. The oxidative stability of poultry meat is influenced by birds' diets and dietary inclusion of CCE with an abundant amount of polyphenolic bioactive compounds that have been demonstrated to scavenge free radicals and chelate metal ions, helping to increase the oxidation resistance of meat. Moreover, the application of CCE to broiler breast meat was associated with a lower thiobarbituric acid reactive substances (TBARS) value and an increased meat shelf life [15].

Digested carbohydrates, protein, and lipids are transferred into the body by certain transporter proteins located in the brush border enterocytes of the small intestine $[27,28]$. These include GLUT1 and GLUT2, which are responsible for monosaccharide transportation (glucose, galactose, fructose, and mannose) across the intestinal membrane [29]. The greater expression of transporter-encoding genes leads to a higher flood of nutrients into the intestinal cells and, subsequently, into the blood [30]. 
Cornelian cherry extract can play an important role in chickens' intestinal health and meat quality owing to its active principle content. Thus, this work investigated different mechanisms and provides new data about the effects of cornelian cherry extract on growth performance, glucose transporters, gut microbes, and meat oxidative stability in broiler chickens.

\section{Materials and Methods}

The management practices and procedures followed animal welfare, ethical norms, and guidelines of the Institutional Animal Care and Use Committee of the Faculty of Veterinary Medicine at Zagazig University.

\subsection{Birds, Diets, and Experimental Design}

A total of 500 male Ross broiler chicks (ROSS 308), on the day of hatching (initial body weight $45.8 \pm 1$ ), were purchased from a commercial hatchery. Chicks were weighed and randomly divided into five treatment groups with 10 replicate pens containing 10 birds each. The study was organized at the Faculty of Veterinary Medicine, Zagazig University, Egypt. The experimental protocol was accepted by the ethics committee of the Institutional Animal Care and Use Committee of Zagazig University, Egypt. All animal experiments were done according to the recommendations described in "The Guide for the Care and Use of Laboratory Animals in scientific investigations" to ensure their welfare, maintain their rights, and cause minimal stress. All chicks were housed in the same environmental and sanitary conditions all over the experimental period. Birds were raised in floor pens with wood shavings (bird density: 10 broilers $/ \mathrm{m}^{2}$ ) in an environmentally controlled room. The photoperiod in all experimental pens was maintained at $23 \mathrm{~L}: 1 \mathrm{D} \mathrm{h}$ for the first 3 days, followed by 20 L:4 D h until the end of the experiment. The relative humidity ranged from 65 to $75 \%$ throughout the trial. During the 1st week, the room temperature was initially set at $33^{\circ} \mathrm{C}$ and then gradually decreased until the final temperature of $23{ }^{\circ} \mathrm{C}$ was reached. The control starter $(\mathrm{d} 1-10 \mathrm{~d})$ and grower-finisher $(\mathrm{d} 11-38)$ diets were formulated to cover the nutrient requirements of Ross broilers according to the nutritional specifications of ROSS [31]. All birds were allowed access to water and feed ad libitum. The birds were offered a basal diet supplemented with (0 (control), 50, 100, 200, and $400 \mathrm{mg} / \mathrm{kg}$ diet of cornelian cherry extract (CCE). The quantities of feed ingredients and the chemical composition of the control diet are listed in Table 1. The proximate analysis of the feed ingredients was done according to the standard procedures of the Association of Official Agricultural Chemists [32]. Asiatic cornelian cherry extract was obtained from Shaanxi Sinuote Biotech Co. Ltd. China. The extract was collected by water alcohol extraction with an extraction ratio of 10:1. The HPLC analysis of the extract based on the manufacturing company was $100 \mathrm{~g}$ of cornelian cherry extract containing 203 parts per thousand (PPT) iridoids (consisting of 85\% loganic acid), 2.8 PPT ellagic acid, 8.9 PPT anthocyanins, and 4.1 PPT flavonols such as quercetin 3-glucuronide, kaempferol galactoside, and kaempferol glucoside.

\subsection{Growth Parameters and Digestibility Trial}

The body weight and feed intake (FI) were estimated during the starter period (d 110) and grower-finisher period (d 11-38) to calculate the body weight gain, FI, and feed conversion ratio for the whole experimental period (d 1-38). The apparent nutrient digestibility was determined with titanium oxide. At 38 days of age, titanium oxide was added to experimental diets at a rate of $5 \mathrm{~g} / \mathrm{kg}$ diet. The excreta from each replicate pen was collected every $8 \mathrm{~h}$ for five days and analyzed for dry matter, crude protein, ether extract, and crude fiber according to the Association of Official Agricultural Chemists [32]. The titanium oxide content in the diets and excreta was analyzed spectrophotometrically after acid digestion in accordance with the method presented by Short et al. [33] The ap- 
parent digestibility coefficient of nutrients was calculated in accordance with the equation presented by McDonald [34].

Apparent nutrient digestibility $=100-[100 \times($ Indicator content $($ diet $) /$ Indicator content (feces) $\times$ Nutrient content (feces)/Nutrient content (diet)]

Table 1. Ingredients and chemical composition of the basal diet (as dry matter).

\begin{tabular}{ccc}
\hline Ingredients, $\mathbf{g} / \mathbf{k g}$ & Starter & Grower-Finisher \\
\hline Yellow corn grain & 57.40 & 60.1 \\
Soybean meal, 47.5\% & 34.66 & 29.00 \\
Corn gluten, 60\% & 3.00 & 4.00 \\
Soybean oil & 1.10 & 3.00 \\
Calcium carbonate & 1.00 & 1.00 \\
Dicalcium phosphate & 1.80 & 1.90 \\
Common salt & 0.30 & 0.30 \\
Premix * & 0.30 & 0.30 \\
DL- Methionine, 98\% & 0.18 & 0.14 \\
Lysine, HCl, 78\% & 0.16 & 0.16 \\
Anti-mycotoxin & 0.10 & 0.10 \\
\hline Chemical Composition & \\
CP \% $\%$ Kalyzed Chem $\%$ & 3004 & 3158 \\
EE \% & 23.01 & 21.10 \\
Ca \% & 3.63 & 5.55 \\
Available P \% & 2.66 & 2.53 \\
Lysine \% & 0.97 & 0.98 \\
Methionine \% & 0.47 & 0.47 \\
\hline
\end{tabular}

* Supplied per kg of diet: Vitamin A, 12000 IU; Vitamin D3, 2200 IU; Vitamin E, 26 IU; Vitamin K3, $6.25 \mathrm{mg}$, Vitamin B1, 3.75 mg; Vitamin B2, $6.6 \mathrm{mg}$; Vitamin B6, $1.5 \mathrm{~g}$; Pantothenic acid, $18.8 \mathrm{mg}$; Vitamin B12, $0.31 \mathrm{mg}$; Niacin, 30 mg; Folic acid, $1.25 \mathrm{mg}$; Biotin, $0.6 \mathrm{mg}$; Fe, $50 \mathrm{mg}$; Mn, $60 \mathrm{mg}$; Cu, 6 mg; I, $1 \mathrm{mg}$; Co, $1 \mathrm{mg}$; Se, $0.20 \mathrm{mg}$; $\mathrm{Zn}, 50 \mathrm{mg}$; Choline chloride, $500 \mathrm{mg}$; ${ }^{* *} \mathrm{ME}$ calculated according to National Research Council 1994; ${ }^{* *} \mathrm{ME}$, metabolic energy; $\mathrm{CP}$, crude protein; $\mathrm{EE}$, ether extract; $\mathrm{CF}$, crude fiber; $\mathrm{Ca}$, calcium; $\mathrm{P}$, Phosphorus.

\subsection{Sample Collection and Analytical Procedures}

At the end of the experimental period, randomly selected birds were weighed and slaughtered.

For serum biochemical measurements, $3 \mathrm{~mL}$ blood samples were collected from each bird and then centrifuged for $15 \mathrm{~min}$ at $2000 \mathrm{rpm}$. Clear serum samples were kept at $-20^{\circ} \mathrm{C}$ until further biochemical analysis.

For meat chemical composition analysis, meat samples were collected from the breast and thigh and then stored at $-20^{\circ} \mathrm{C}$ until chemical analysis.

For the meat antioxidant analysis, breast meat samples were frozen immediately until the total phenolic content (TPC) and thiobarbituric acid reactive substance (TBARS) content were analyzed and the 2,2-Diphenyl-1-picrihydrzyl (DPPH) assay and Ferric reducing antioxidant power (FRAP) were conducted at 7 and 90 days of storage at $-20{ }^{\circ} \mathrm{C}$.

For the molecular analysis, breast meat samples were collected and stored at $-80^{\circ} \mathrm{C}$ until the analysis of antioxidant-related genes. The small intestine (jejunal part) was separated and the digesta was squeezed out from it and rinsed 3 times in PBS $\left(\mathrm{NaH}_{2} \mathrm{PO}_{4}\right.$, $1.47 \mathrm{mmol} / \mathrm{L} ; \mathrm{Na}_{2} \mathrm{HPO}_{4}, 8.09 \mathrm{mmol} / \mathrm{L}$; and $\left.\mathrm{NaCl}, 145 \mathrm{mmol} / \mathrm{L}\right)$. One square centimeter of the distal jejunum immediately before the Meckel's diverticulum was dissected and kept in Trizol reagent at $-80{ }^{\circ} \mathrm{C}$ until the analysis of nutrient transporter encoding genes.

\subsection{Serum Biochemical Analysis}

Serum aspartate aminotransferase (AST), and alanine aminotransferase (ALT), total cholesterol (TC), triglycerides (TGs), high-density lipoprotein cholesterol (HDL-C), 
low-density lipoprotein cholesterol (LDL-C), very-low-density lipoprotein cholesterol (VLDL-C), creatinine, uric acid, total protein, globulin, and albumin concentrations were determined using commercial diagnostic kits (Spinreact Co., Santa Coloma, Spain).

\subsection{Chemical Copmostion of Meat}

The dry matter, crude protein, fat and ash contents of breast and thigh meat were analyzed according to the Association of Official Analytical Chemists (AOAC) [32].

\subsection{Antioxidant Potential of Broiler Meat}

Breast meat samples $(5 \mathrm{~g})$ were mixed with phosphate buffer $(20 \mathrm{~mL} ; \mathrm{pH} 7.4)$ and glycerol $(20 \mathrm{~mL} ; 20 \%)$ and homogenized and filtered to ensure they were free from connective tissues.

\subsubsection{Total Phenolic Content (TPC)}

The total phenolic content of breast meat was measured in accordance with [35]. Briefly, a previously prepared meat sample $(100 \mu \mathrm{L})$, distilled water, $2.5 \mathrm{~mL}$ of $95 \%$ ethanol $(500 \mu \mathrm{L})$, and $50 \%$ Folin-Ciocalteu reagent $(250 \mu \mathrm{L})$ were mixed. This mixture settled for $5 \mathrm{~min}$, and then $5 \% \mathrm{Na}_{2} \mathrm{CO}_{3}(500 \mu \mathrm{L})$ was added. The mixture was rotated in a vortex meter and left in a dark place for $1 \mathrm{~h}$. The absorbance of samples was measured at $725 \mathrm{~nm}$ via a spectrophotometer. The quantity of TPC in meat was measured as Gallic acid equivalents (milligrams of gallic acid per $100 \mathrm{~g}$ of meat sample).

\subsubsection{2,2-Diphenyl-1-picrihydrzyl (DPPH) Assay}

The DPPH scavenging capacity of the meat sample was calculated as described by [36]. The DPPH A solution $(0.25 \mathrm{mM})$ was formed in methanol. Each sample $(100 \mathrm{~mL})$ was mixed with $100 \mu \mathrm{L}$ of DPPH solution and maintained for $30 \mathrm{~min}$ at $25^{\circ} \mathrm{C}$ in a dark place, and the sample absorbance was read at $517 \mathrm{~nm}$ by a spectrophotometer. The scavenging activity percentage of DPPH in the meat was determined with the following equation:

$$
\text { Scavenging activity of DPPH }(\%)=1-\left[\mathrm{A}_{1}-\mathrm{A}_{2}\right] \times 100
$$

Blank absorbance

$\mathrm{A}_{1}=$ Sample absorbance; $\mathrm{A}_{2}=$ Blank absorbance

\subsubsection{Ferric Reducing Antioxidant Power (FRAP)}

FRAP in meat was detected according to Oyaizu [37]. A 200- $\mu$ L homogenized meat sample was mixed with sodium phosphate buffer $(500 \mu \mathrm{L})$. After that, the prepared solution was maintained in a water bath for $20 \mathrm{~min}$ at $50^{\circ} \mathrm{C}$ and then centrifuged for $10 \mathrm{~min}$ with trichloroacetic acid $(2.5 \mathrm{~mL})$ and ferric chloride solution $(100 \mu \mathrm{L})$. The spectrophotometric absorbance of the samples was measured at $700 \mathrm{~nm}$. The FRAP was estimated as $\mu \mathrm{mol} / \mathrm{Fe}^{2}+/ \mathrm{g}$ meat.

\subsection{TBARS Assay}

Lipid oxidation in breast meat was evaluated based on the malondialdehyde (MDA) content, as the MDA concentration in breast meat was determined as previously described by [38]. Briefly, perchloric acid $(27 \mathrm{~mL})$ was added to $5 \mathrm{~g}$ breast meat samples and then homogenized and filtered. Supernatant samples were mixed with thiobarbituric acid $(2 \mathrm{~mL})$ and incubated for $20 \mathrm{~min}$ in a water bath $\left(100^{\circ} \mathrm{C}\right)$. Consequently, direct cooling and centrifugation were done for $15 \mathrm{~min}$, and the absorbance was measured by a spectrophotometer at $532 \mathrm{~nm}$. The values are expressed as milligrams of malondialdehyde per kilogram of meat.

\subsection{Real-Time PCR to Assess Nutrient Transporter Encoding Genes}

Total mRNA was extracted from jejunum and breast meat samples $(n=10$ per treatment) using Trizol reagent (TaKaRa Biotechnology Co. Ltd., Dalian, Liaoning, China). The isolated RNA was treated with the RNeasy Mini Kit; Qiagen, Cat. No. 74104 according to 
the manufacturer's guidelines. The quantity and purity of the total RNA were determined by a NanoDrop ND-8000 spectrophotometer (Thermo Fisher Scientific, Waltham, USA). Complementary DNA (cDNA) was obtained by reverse-transcription of isolated RNA samples using RevertAidTM H Minus kits (Fermentas Life Science, Pittsburgh, PA, USA). One microliter of this cDNA was mixed with $2 \times$ maxima SYBR Green PCR mix $(12.5 \mu \mathrm{L})$ and RNase free water $(10.5 \mu \mathrm{L})$, and then, $0.5 \mu \mathrm{L}$ of each forward and reverse primer for the selected genes was added. The primers' sequences of genes encoding the glucose transporter and antioxidant enzymes are described in Table 2. Glyceraldehyde-3-phosphate dehydrogenase (GAPDH) was selected as a reference gene.

Table 2. Primer sequences and target genes used for Q-PCR reactions.

\begin{tabular}{|c|c|c|c|}
\hline Gene & Gene Full Name & Primer Sequence $\left(5^{\prime}-3^{\prime}\right)$ & Reference No \\
\hline \multicolumn{4}{|c|}{ Glucose transporters } \\
\hline GLUT1 & Glucose transporter 1 & $\begin{array}{c}\text { F-TCCTCCTGATCAACCGCAAT } \\
\text { R-TGTGCCCCGGAGCTTCT }\end{array}$ & NM_205209.1 \\
\hline GLUT2 & Glucose transporter 2 & $\begin{array}{c}\text { F-TGATCGTGGCACTGATGGTT } \\
\text { R-CCACCAGGAAGAC } \downarrow \text { GGAGATA }\end{array}$ & NM_207178.1 \\
\hline SGLT-1 & Sodium-dependent glucose transporter & $\begin{array}{l}\text { F-TGCCGGAGTATCTGAGGAAG } \\
\text { R-CCCCATGGCCAACTGTATAA }\end{array}$ & XM_015275173.2 \\
\hline \multicolumn{4}{|c|}{ Antioxidant related genes } \\
\hline GPX1 & Glutathione peroxidase & $\begin{array}{l}\text { F- GCTGTTCGCCTTCCTGAGAG } \\
\text { R- GTTCCAGGAGACGTCGTTGC }\end{array}$ & NM_001277853.1 \\
\hline SOD1 & Superoxide dismutase & $\begin{array}{l}\text { F- CACTGCATCATTGGCCGTACCA } \\
\text { R- GCTTGCACACGGAAGAGCAAGT }\end{array}$ & NM_205064.1 \\
\hline$C A T$ & Catalase & $\begin{array}{l}\text { F- TGGCGGTAGGAGTCTGGTCT } \\
\text { R- GTCCCGTCCGTCAGCCATTT }\end{array}$ & NM_001031215.1 \\
\hline \multicolumn{4}{|c|}{ House keeping } \\
\hline GAPDH & Glyceraldahyde-3-phosphate dehydrogenase & $\begin{array}{l}\text { F-GGTGGTGCTAAGCGTGTTA } \\
\text { R-CCСTCCACAATGCCAA }\end{array}$ & NM205518 \\
\hline TBP & TATA-binding protein & $\begin{array}{l}\text { F: GTCCACGGTGAATCTTGGTT } \\
\text { R: GCGCAGTAGTACGTGGTTCTC }\end{array}$ & Acc:8484 \\
\hline
\end{tabular}

\subsection{Microbiological Assay}

Spread plate counting method for different microbes: One gram of cecal content was mixed with $9 \mathrm{~mL}$ phosphate-buffered saline and vortexed for $1 \mathrm{~min}$. Samples were serially diluted in sterile diluents ( $0.5 \mathrm{~g} / \mathrm{kg}$ peptone water in distilled water). De Man, Rogosa, and Sharpe (MRS, CM1153, Oxoid, Basingstoke Hampshire, UK) agar medium was used for the enumeration of Lactobacilli (MRS, CM1153, Oxoid), Bifidus selective agar was utilized to determine the Bifidobacteria content (BSM-Agar, 88517, Sigma, St. Louis, MO, USA), and violet-red bile glucose agar (VRBG, CM485, Oxoid) was used to determine the Escherichia coli content. After incubation under appropriate conditions for each group of bacteria (72 h at $37^{\circ} \mathrm{C}$ under anaerobic conditions for lactobacilli and Bifidobacteria and $48 \mathrm{~h}$ at $39^{\circ} \mathrm{C}$ under aerobic conditions for E. coli), colonies were counted on the plates, and the microbial population was expressed as $\log _{10} \mathrm{CFU} / \mathrm{g}$ of cecal content.

\subsection{Statistical Analysis}

The data analysis was conducted using the general linear model (GLM) procedure of Statistical Package for the Social Sciences, software (SPSS), after confirming the homogeneity among experimental groups using the Levene test and the normality using the Shapiro-Wilk test. Tukey's test was used to test for significant differences between the mean values. All results are expressed as the standard error of the mean (SEM), and the statistical significance was set at $p<0.05$. Cecal colony-forming unit (CFU) data were converted to $\log _{10} \mathrm{CFU}$ numbers before analysis. The fold change was measured by the following equation: (B-A)/A where the lowest value is $\mathrm{A}$ and the highest value is $\mathrm{B}$. Relative fold changes in the expression of target genes were calculated by the $2^{-\Delta \Delta} \mathrm{Ct}$ method using the GAPDH gene as an internal control gene to normalize the target gene expression levels [39]. 


\section{Results}

\subsection{Growth Performance and Nutrient Digestibility}

The growth performance parameters of the total growing period and nutrient digestibility are shown in Table 3. The body weight gain (BWG) was significantly greater $(p<0.05)$ in groups fed 100, 200, and $400 \mathrm{mg} / \mathrm{kg}$ of CCE when compared with the control group. Moreover, the highest BWG was observed in the group fed $200 \mathrm{mg} / \mathrm{kg}$ of CCE (increased by $9 \%$ in comparison with the control group). The feed conversion ratio (FCR) was improved in all groups fed CCE supplemented diets at different levels, and the biggest improvement in FCR was detected in the group fed diets supplemented with 100 or $200 \mathrm{mg} / \mathrm{kg}$ CCE. Concerning the nutrient digestibility, the groups fed 100 or $200 \mathrm{mg} / \mathrm{kg}$ $\mathrm{CCE}$ showed higher dry matter (DM) contents and CP digestibility levels in comparison with diets containing other levels of CCE, while the control group showed the lowest level of DM digestibility. No significant difference in the digestibility of $\mathrm{CF}$ was observed among the different groups.

Table 3. Effect of different levels of cornelian cherry extract (CCE) on growth performance and nutrient digestibility of broiler chickens.

\begin{tabular}{cccccccc}
\hline \multicolumn{7}{c}{ CCE (mg/kg Diet) } \\
\hline Parameters & $\mathbf{0}$ & $\mathbf{5 0}$ & $\mathbf{1 0 0}$ & $\mathbf{2 0 0}$ & $\mathbf{4 0 0}$ & $p$-Value & SEM \\
\hline Total growing period & & & & & & & \\
BW (g/bird) & $2423^{\mathrm{c}}$ & $2439^{\mathrm{b}, \mathrm{c}}$ & $2508^{\mathrm{b}}$ & $2649^{\mathrm{a}}$ & $2503^{\mathrm{b}}$ & $<0.001$ & 14.10 \\
BWG (g/bird) & $2377^{\mathrm{c}}$ & $2393^{\mathrm{b}, \mathrm{c}}$ & $2462^{\mathrm{b}}$ & $2603^{\mathrm{a}}$ & $2457^{\mathrm{b}}$ & $<0.001$ & 14.12 \\
FI (g/bird) & $4331^{\mathrm{b}}$ & $4219^{\mathrm{c}}$ & $4224^{\mathrm{c}}$ & $4503^{\mathrm{a}}$ & $4400^{\mathrm{b}}$ & $<0.001$ & 17.53 \\
FCR & $1.82^{\mathrm{a}}$ & $1.76^{\mathrm{a}, \mathrm{b}, \mathrm{c}}$ & $1.72^{\mathrm{c}}$ & $1.73^{\mathrm{b}, \mathrm{c}}$ & $1.79^{\mathrm{a}, \mathrm{b}}$ & $<0.001$ & 0.01 \\
Digestibility \% & & & & & & & \\
Dry matter & $69.37^{\mathrm{d}}$ & $71.87^{\mathrm{b}, \mathrm{c}}$ & $73.33^{\mathrm{a}, \mathrm{b}}$ & $74.80^{\mathrm{a}}$ & $71.54^{\mathrm{c}}$ & $<0.05$ & 0.50 \\
Crude protein & $62.45^{\mathrm{c}}$ & $63.63^{\mathrm{b}, \mathrm{c}}$ & $65.92^{\mathrm{a}, \mathrm{b}}$ & $69.22^{\mathrm{a}}$ & $63.69^{\mathrm{b}}$ & $<0.001$ & 0.40 \\
Crude fiber & $27.30^{27.37}$ & 27.95 & 29.47 & 29.18 & $<0.20$ & 0.60 \\
\hline
\end{tabular}

BW (body weight); BWG = body weight gain; FI = feed intake; FCR = feed conversion ratio; Number of birds $/$ replicates $=10 ;{ }^{a-d}$ Means within a row carrying different superscript letters denote significant differences $(p<0.05)$.

\subsection{Serum Biochemical Parameters}

Data regarding the impact of CCE on serum biochemical parameters after 38 days are shown in Table 4. The levels of serum AST, ALT, creatinine, uric acid, total protein, albumin, globulin, TGs, HDL-C, and VLDL-C were not affected by dietary CCE $(p>0.05)$. However, total cholesterol and LDL-C concentrations were significantly reduced $(p<0.05)$ in the group supplemented with $400 \mathrm{mg} / \mathrm{kg}$ of CCE in comparison with the other groups.

Table 4. Effect of different levels of cornelian cherry extract (CCE) on serum biochemical parameters of broiler chickens.

\begin{tabular}{cccccccc}
\hline & \multicolumn{7}{c}{ CCE (mg/kg Diet) } \\
\hline Parameter & $\mathbf{0}$ & $\mathbf{5 0}$ & $\mathbf{1 0 0}$ & $\mathbf{2 0 0}$ & $\mathbf{4 0 0}$ & $\boldsymbol{p}$-Value & SEM \\
\hline ALT, U/L & 20.82 & 20.78 & 20.98 & 20.60 & 19.58 & 0.18 \\
AST, U/L & 55.16 & 55.40 & 54.00 & 54.64 & 53.58 & 0.06 & 0.40 \\
Uric acid, mg/dL & 5.70 & 5.96 & 5.74 & 6.04 & 5.91 & 0.55 & 0.48 \\
Creatinine, mg/dL & 0.96 & 1.02 & 0.98 & 1.1 & 0.94 & 0.69 & 0.06 \\
Total Cholesterol, mg/dL & $109.16^{\mathrm{a}}$ & $109.30^{\mathrm{a}}$ & $107.76^{\mathrm{a}}$ & $109.34^{\mathrm{a}}$ & $100.78^{\mathrm{b}}$ & $<0.001$ & 3.62 \\
TGs, mg/dL & 61.18 & 60.78 & 61.24 & 60.32 & 60.28 & 0.34 & 0.38 \\
HDL-C, mg/dL & 43.34 & 44.58 & 44.48 & 44.78 & 43.90 & 0.17 & 0.36 \\
LDL-C, mg/dL & $53.58^{\mathrm{a}}$ & $52.56^{\mathrm{a}}$ & $51.03^{\mathrm{a}}$ & $52.49^{\mathrm{a}}$ & $44.82^{\mathrm{b}}$ & 0.02 & 4.20 \\
VLDL-C, mg/dL & 12.23 & 12.16 & 12.24 & 12.06 & 12.00 & 0.34 & 0.02 \\
Total protein (g/dL) & 4.43 & 4.40 & 4.41 & 4.47 & 4.44 & 0.96 & 0.03 \\
Albumin (g/dL) & 2.28 & 2.25 & 2.32 & 2.25 & 2.25 & 0.97 & 0.03 \\
Globulin (g/dL) & 2.15 & 2.16 & 2.09 & 2.21 & 2.19 & 0.96
\end{tabular}

a,b Means with different superscripts within the same row differ significantly $(p<0.05)$; ALT: Alanine aminotransferase, AST: Aspartate aminotransferase, TGs: Triglycerides, HDL-C: high- density lipoprotein cholesterol, LDL-C: low-density lipoprotein cholesterol, VLDL-C: very-low density lipoprotein cholesterol. 


\subsection{Chemical Composition of Meat:}

The dry matter, crude protein, fat, and ash contents both breast and thigh meat were not affected $(p>0.05)$ by dietary CCE, as shown in Table 5.

Table 5. Effect of different levels of cornelian cherry extract (CCE) on breast and thigh muscle chemical analysis of broiler chickens $\%$ on wet basis.

\begin{tabular}{cccccccc}
\hline \multicolumn{7}{c}{ CCE (mg/kg Diet) } \\
\hline Parameters & $\mathbf{0}$ & $\mathbf{5 0}$ & $\mathbf{1 0 0}$ & $\mathbf{2 0 0}$ & $\mathbf{4 0 0}$ & $p$-Value & SEM \\
\hline \multicolumn{7}{c}{ Breast } & Muscle Analysis \% of Wet Basis \\
\hline DM & 25.76 & 25.26 & 25.61 & 24.73 & 25.35 & 0.614 & 0.21 \\
CP & 23.61 & 23.04 & 24.19 & 23.24 & 23.92 & 0.322 & 0.19 \\
EE & 4.52 & 4.52 & 4.63 & 4.64 & 4.56 & 0.949 & 0.06 \\
Ash & 1.28 & 1.20 & 1.27 & 1.22 & 1.25 & 0.864 & 0.02 \\
\hline \multicolumn{7}{c}{ Thigh Muscles Analysis\% of Wet Basis } \\
\hline DM & 28.42 & 28.34 & 27.21 & 26.52 & 28.36 & 0.273 & 0.34 \\
CP & 22.06 & 20.66 & 20.38 & 21.95 & 21.74 & 0.051 & 0.24 \\
EE & 6.94 & 7.21 & 6.62 & 6.31 & 6.91 & 0.087 & 0.11 \\
Ash & 1.18 & 1.23 & 1.29 & 1.11 & 1.24 & 0.399 & 0.03 \\
\hline
\end{tabular}

Dry matter: DM, crude protein: $\mathrm{CP}$, ether extract: EE.

\subsection{Gene Expression of Glucose Transporter}

The mRNA expression levels of the jejunal nutrient transport genes (GLUT1, GLUT2, and SGLT-1) are presented in Figure 1. The expression levels of glucose transporter genes (GLUT-1, GLUT-2, and SGLT-1) were significantly upregulated in groups fed CCE, and the highest level was found in the group supplemented with $200 \mathrm{mg} / \mathrm{kg}$ of CCE $(p<0.05)$ with fold changes of 2.55, 2.32, and 2.36, respectively. The aforementioned upregulation was declined in the group supplemented with $400 \mathrm{mg} / \mathrm{kg}$ of CCE. Of note, GLUT1 expression in the group supplemented with $50 \mathrm{mg} / \mathrm{kg}$ of CCE showed no significant difference as compared with the control group. Moreover, SGLT-1 expression was significantly upregulated in all groups supplemented with CCE, and the maximum level of upregulation was found in the group supplemented with $200 \mathrm{mg} / \mathrm{kg}$ of CCE.

\subsection{Gut Microbiota}

The gut microbiota data are presented in Table 6. The mean cecal populations of beneficial lactobacilli, bifidobacteria significantly increased after dietary supplementation with 100,200 , or $400 \mathrm{mg} / \mathrm{kg}$ of CCE when compared with the control group $(p<0.05)$. The population of E. coli in cecal samples significantly decreased $(p<0.05)$ as the CCE level increased, and the lowest reduction of $E$. coli was observed with diets supplemented with 200 or $400 \mathrm{mg} / \mathrm{kg}$ of CCE.

Table 6. Effect of different levels of Cornelian cherry extract (CCE) on cecal microorganisms ( $\log _{10} \mathrm{cfu} / \mathrm{g}$ fresh digesta) of broiler chickens at slaughter.

\begin{tabular}{cccccccc}
\hline \multicolumn{7}{c}{ CCE (mg/kg Diet) } \\
\hline & $\mathbf{0}$ & $\mathbf{5 0}$ & $\mathbf{1 0 0}$ & $\mathbf{2 0 0}$ & $\mathbf{4 0 0}$ & $p$-Value & SEM \\
\hline Bifidobacterium & $6.17^{\mathrm{b}}$ & $6.57^{\mathrm{b}}$ & $7.70^{\mathrm{a}}$ & $7.90^{\mathrm{a}}$ & $8.17^{\mathrm{a}}$ & $<0.01$ & 0.20 \\
Lactobacillus & $6.50^{\mathrm{d}}$ & $6.70^{\mathrm{d}}$ & $7.73^{\mathrm{c}}$ & $8.13^{\mathrm{b}}$ & $8.87^{\mathrm{a}}$ & $<0.001$ & 0.10 \\
Escherichia coli & $8.23^{\mathrm{a}}$ & $7.9^{\mathrm{ab}}$ & $7.23^{\mathrm{b}}$ & $6.47^{\mathrm{c}}$ & $6.27^{\mathrm{c}}$ & $<0.008$ & 0.16 \\
\hline
\end{tabular}

Number of birds / replicate $=10{ }^{a-d}$ Means within a row carrying different superscript letters denote significant differences $(p<0.05)$. 


\section{Fig 1}

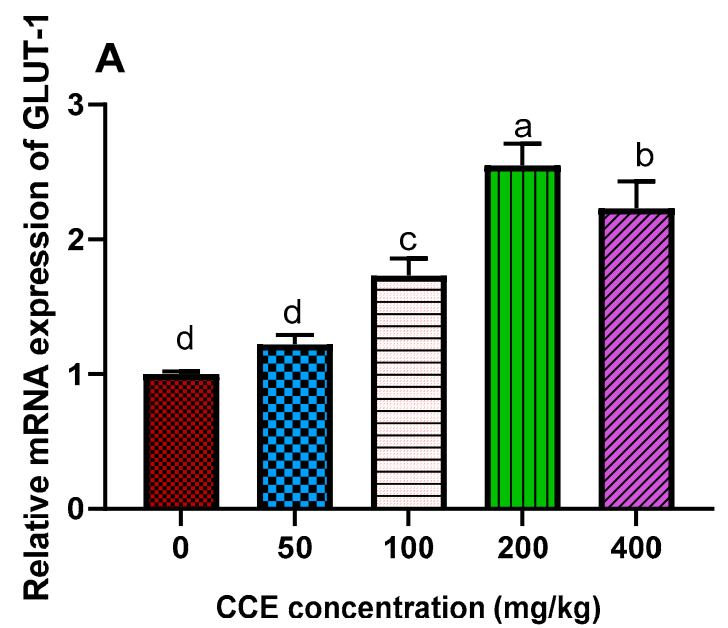

B

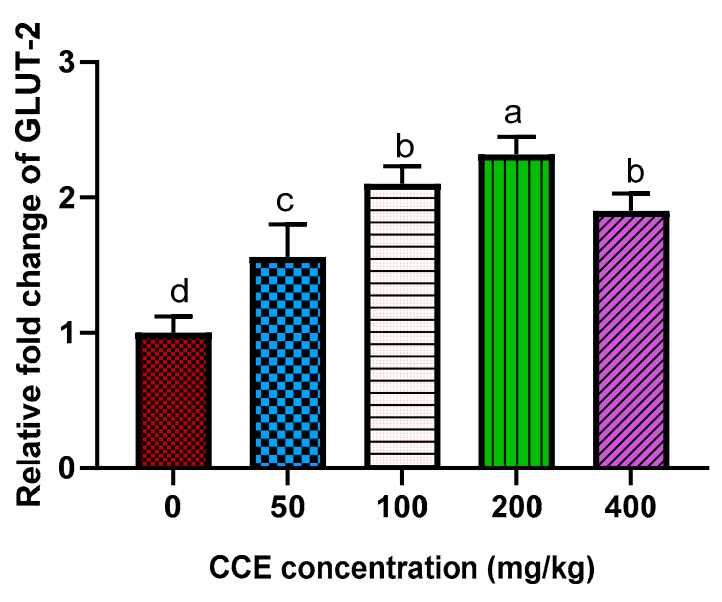

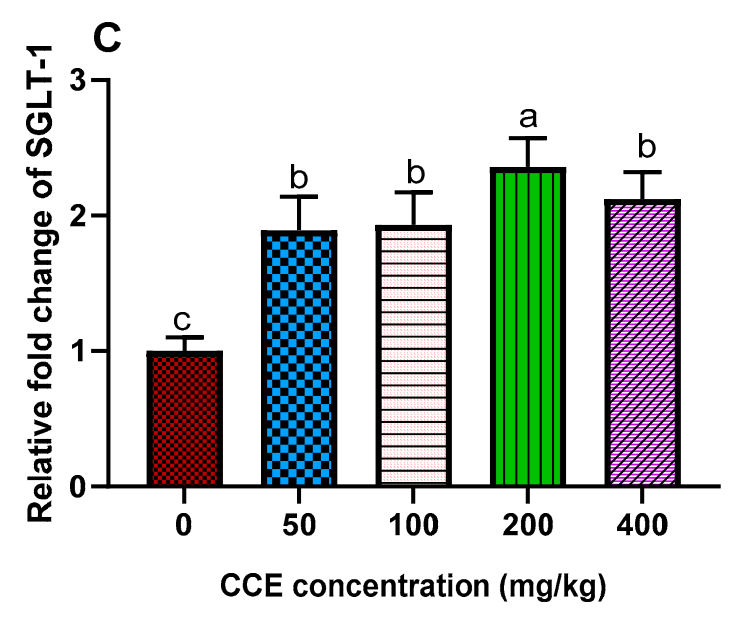

Figure 1. Effect of different levels of cornelian cherry extract (CCE) on glucose transporters genes expression (glucose transporter-1 (A) GLUT-1, glucose transporter-2 (B) GLUT-2, Sodium-dependent glucose transporter (C) SGLT-1. ${ }^{\text {a-d }}$ Means within the same column carrying different superscripts are significantly different at $p<0.05$. Values are means \pm standard error. Number of birds $/$ replicates $=10$

\subsection{Antioxidant-Related Genes}

The expression patterns of selected antioxidant-related genes (glutathione peroxidase, $G P x$, superoxide dismutase, $S O D$ and catalase, $C A T$ ) are presented in Figure 2. The highest expression levels of GPX were observed in groups supplemented with $400 \mathrm{mg} / \mathrm{kg}$ of CCE followed by the groups fed $200 \mathrm{mg} / \mathrm{kg}$ of CCE then 50 and $100 \mathrm{mg} / \mathrm{kg}$ of CCE. The mRNA expression of GPx was significantly upregulated $(p<0.05)$ in the groups fed 200 or $400 \mathrm{mg} / \mathrm{kg}$ of CCE compared with groups fed 50 or $100 \mathrm{mg} / \mathrm{kg}$ of CCE when compared with the control group. The mRNA expression level of $S O D$ was significantly increased as the CCE level increased when compared with the control. The highest expression levels of catalase were observed in groups supplemented with 200 or $400 \mathrm{mg} / \mathrm{kg}$ of CCE followed by the groups fed 50 or $100 \mathrm{mg} / \mathrm{kg}$ of CCE when compared with the control group. 
Fig 2
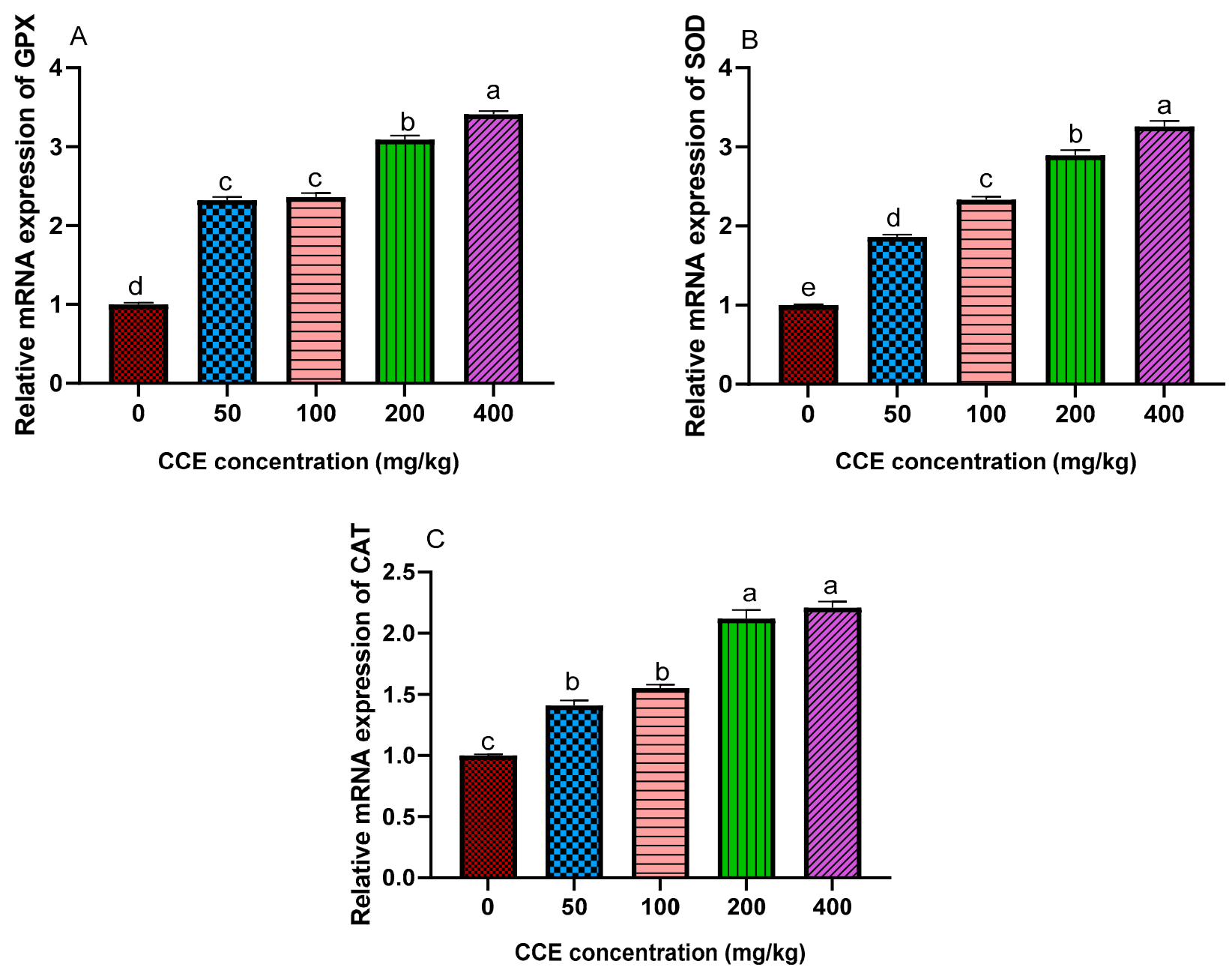

Figure 2. Effect of different levels of cornelian cherry extract (CCE) on (glutathione peroxidase, (GPx) (A), superoxide dismutase, $(S O D)(\mathbf{B})$ and catalase, $(C A T)(\mathbf{C}) .{ }^{\text {a-e }}$ Means with a row carrying different superscripts are significantly different at $p<0.05$. Values are means \pm standard error. Number of birds $/$ replicates $=10$.

\subsection{Antioxidant Potential of Breast Meat}

Data from the analysis of the total phenolic content (TPC), 2,2-diphenyl-1-picrihydrzyl (DPPH) assay, and ferric reducing antioxidant power (FRAP) are presented in Table 5.

\subsubsection{Total Phenolic Content (TPC) in Breast Meat}

After a short storage period ( 7 days), the TPC content of breast meat was significantly increased with an increasing level of dietary CCE. After a long storage period (at day 90), the highest values of TPC were observed in the meat of bird groups fed 200 or $400 \mathrm{mg} / \mathrm{kg}$ of CCE.

\subsubsection{The Free (DPPH) Radical Scavenging Activity}

The DPPH activity significantly increased $(p<0.05)$ in breast meat from groups fed dietary CCE in a dose-dependent manner, even after 90 days of storage.

\subsubsection{FRAP Reducing Activity}

The capacity of the breast myofibrillar protein to reduce $\mathrm{Fe}^{3+}$ to $\mathrm{Fe}^{2+}$ was greater in the meat of groups fed an increased level of dietary CCE. This capacity was increased after 90 days of storage by 1.1 and 1.7 times, respectively, in the meat from groups fed 200 and $400 \mathrm{mg} / \mathrm{kg}$ of CCE when compared to the control group. 


\subsection{Lipid Peroxidation}

Lipid peroxidation, determined as the concentration of MDA in breast meat after 7 and 90 days of storage, is presented in Table 7 . At day 7 (short term storage), the MDA level was significantly reduced $(p<0.05)$ in all groups supplemented with CCE, and the lowest levels were observed in the groups fed 200 and $400 \mathrm{mg} / \mathrm{kg}$ of CCE when compared with the control group. At day 90 (long-term storage), all groups supplemented with CCE, except the group fed $50 \mathrm{mg} / \mathrm{kg}$, showed reduced levels of MDA when compared with the control group. The greatest reduction in MDA was observed in the group fed $400 \mathrm{mg} / \mathrm{kg}$ of CCE. Moreover, the meat MDA content in the group supplemented with $400 \mathrm{mg} / \mathrm{kg}$ of CCE was decreased by up to $59.5 \%$ and $68.6 \%$ after 7 and 90 days of storage, respectively, when compared with the control $(p<0.05)$.

Table 7. Effect of different levels of cornelian cherry extract (CCE) on breast meat total phenolic content oxidative stability and lipid peroxidation during freezing storage at $-20^{\circ} \mathrm{C}$.

\begin{tabular}{cccccccc}
\hline \multicolumn{7}{c}{ CCE (mg/kg Diet) } \\
\hline Parameters & $\mathbf{0}$ & $\mathbf{5 0}$ & $\mathbf{1 0 0}$ & $\mathbf{2 0 0}$ & $\mathbf{4 0 0}$ & $p$-Value & SEM \\
\hline TPC at d 7 of storage & $68.71^{\mathrm{e}}$ & $111.06^{\mathrm{d}}$ & $124.06^{\mathrm{c}}$ & $131.68^{\mathrm{b}}$ & $143.72^{\mathrm{a}}$ & 4.91 & $<0.001$ \\
TPC at d 90 of storage & $49.77^{\mathrm{d}}$ & $96.71^{\mathrm{c}}$ & $109.51^{\mathrm{b}}$ & $121.95^{\mathrm{a}}$ & $128.02^{\mathrm{a}}$ & 3.27 & $<0.001$ \\
$\begin{array}{c}\text { DPPH assay at d 7 of } \\
\text { storage }\end{array}$ & $86.99^{\mathrm{e}}$ & $118.20^{\mathrm{d}}$ & $133.67^{\mathrm{c}}$ & $148.58^{\mathrm{b}}$ & $155.88^{\mathrm{a}}$ & 4.45 & $<0.001$ \\
$\begin{array}{c}\text { DPPH at d 90 of storage } \\
\text { FRAP assay at d 7 of }\end{array}$ & $77.58^{\mathrm{e}}$ & $106.93^{\mathrm{d}}$ & $124.61^{\mathrm{c}}$ & $134.58^{\mathrm{b}}$ & $144.03^{\mathrm{a}}$ & 3.89 & $<0.001$ \\
$\quad 229.44^{\mathrm{e}}$ & $435.81^{\mathrm{d}}$ & $447.99^{\mathrm{c}}$ & $514.62^{\mathrm{b}}$ & $618.37^{\mathrm{a}}$ & 8.09 & $<0.001$ \\
$\begin{array}{c}\text { FRAP assay at d } 90 \text { of } \\
\text { storage }\end{array}$ & $175.44^{\mathrm{d}}$ & $292.34^{\mathrm{c}}$ & $301.89^{\mathrm{c}}$ & $369.88^{\mathrm{b}}$ & $474.55^{\mathrm{a}}$ & 7.51 & $<0.001$ \\
$\begin{array}{c}\text { MDA content at d 7 of } \\
\text { storage }\end{array}$ & $0.47^{\mathrm{a}}$ & $0.26^{\mathrm{b}}$ & $0.22^{\mathrm{c}}$ & $0.15^{\mathrm{d}}$ & $0.19^{\mathrm{d}}$ & 0.12 & $<0.03$ \\
$\begin{array}{c}\text { MDA content at d 90 of } \\
\text { storage }\end{array}$ & $0.67^{\mathrm{a}}$ & $0.46^{\mathrm{a}}$ & $0.30^{\mathrm{b}}$ & $0.28^{\mathrm{b}}$ & $0.21^{\mathrm{c}}$ & 0.03 & $<0.008$
\end{tabular}

TPC = Total phenolic contents; DPPH = 2,2-Diphenyl-1-picrihydrzyl; FRAP = Ferric reducing antioxidant power $\mathrm{MDA}=$ malondialdehyde; Number of birds $/$ replicate $=10{ }^{\mathrm{a}-\mathrm{e}}$ Means within a row carrying different superscript letters denote significant differences $(p<0.05)$.

\section{Discussion}

Natural plant extracts have been shown to improve the performance of birds by augmenting nutrient utilization and bacterial modulation in the gastrointestinal tract as well as improving the meat quality and oxidative stability. Among these natural products, polyphenols gained growing interest due to their numerous functional properties. Cornelian cherry extract (CCE) has been reported to have an abundance of polyphenolic compounds. The current study demonstrated that CCE could be used to improve the growth rate of broilers by controlling nutrient utilization and absorption and the gut microbiota, and increasing the shelf-life storage of poultry meat by boosting the oxidative stability of meat. In the present study, supplementation of CCE has been shown to improve the feed efficiency of birds by lowering the overall FCR by nearly $5 \%$ in the group supplemented with 100 and $200 \mathrm{~g} / \mathrm{kg}$ CCE. Herein, CCE supplementation has been shown to improve the feed efficiency of birds by lowering the overall FCR by nearly $5 \%$ in groups supplemented with 100 or $200 \mathrm{~g} / \mathrm{kg}$ CCE. The present results are consistent with the results of other researchers [40], who reported that the dietary inclusion of different phenolic compounds for broilers had a positive impact on growth performance parameters. Plant-rich phenolics could promote the growth performance of broilers $[40,41]$ through their potential to improve the antioxidant status of the gut [42]. Furthermore, the application of green tea extract, which is rich in catechins, at concentrations of 100 or $200 \mathrm{mg} / \mathrm{kg}$, in feed has been found to boost the growth performance of broiler chickens [43,44]. Additionally, Herrero-Encinas et al. [45] showed that dietary supplementation with olive extract rich in polyphenolic compounds significantly improved the weight gain and feed conversion ratio of broilers. Similarly, the body weight gain of broiler chickens improved after feeding with grape seed proanthocyanidin extract [46]. Additionally, a sugarcane-served polyphe- 
nol mix had a positive effect on the growth performance of broilers and modulated the negative effect of heat exposure [47]. Moreover, the consumption of berries, which have numerous bioactive phenolic compounds, was shown to upregulate the expression of growth-related genes such as insulin-like growth factor binding proteins [48]. Furthermore, certain phytogenic derived agents could improve gastrointestinal barrier function and nutrient absorption [49,50]. Sarker et al. [51] showed that feeding with Cornus officinalis had no adverse effect on the growth rate in broilers.

On the other hand, the concentrations of serum AST and ALT indirectly reveal the liver health status and increases in their levels are considered markers of liver damage [52]. In addition, the function of kidney can be estimated via the decrease or increase in of urea and creatinine serum levels. Herein, serum concentration of AST, ALT, uric acid, and creatinine were not affected by dietary CCE and were within normal range, which indicates healthy liver and kidney functions in both control and CCE supplemented groups. Moreover, the current study revealed that higher levels of dietary CCE $(400 \mathrm{mg} / \mathrm{kg})$ significantly reduced total cholesterol and LDL-C levels in serum. Similarly, Zhang et al. [53] specified that the feeding of broiler chickens with Chinese bayberry leaves, which are rich in phenolic compounds, significantly reduced the serum cholesterol concentration. The presence of a higher concentration of proanthocyanidins in sorghum, which has antioxidative properties, was also reported to be associated with cholesterol-lowering [54]. Furthermore, the higher concentration of anthocyanins in cornelian cherry powder had a hypercholesterolemic effect in rats via augmenting peroxisome proliferator-activated receptor (PPAR $\alpha$ ) protein expression and controlling reactive oxygen species (ROS) production and, subsequently, the inflammatory process [55]. Additionally, serum protein and globulin concentrations were not significantly different between treatments and were within the normal range [56]. Similarly, supplementation of broiler chickens with polyphenol extract did not affect their serum protein and globulin concentrations [57]. In addition, supplementation with CCE had no significant effects on the chemical composition (DM, CP, EE and Ash) of meat; these results are in accordance with Gopi et al. [40].

Additionally, the enhanced growth performance of the broilers could have resulted from increasing levels of probiotic bacteria such as lactobacilli and Bifidobacteria. Moreover, the population of these beneficial bacteria increased in groups supplemented with higher levels of CCE. These positive effects could be related to the role of phenolic-rich cornelian cherry extract on the intestinal microflora, leading to an increase in the concentration of beneficial bacteria (probiotic effect) or inhibiting the growth of pathogenic species (antimicrobial effect) [58]. In agreement with our results, Bifidobacterium and Lactobacillus have been shown to be the most widely used probiotic bacteria, exerting health-promoting properties, such as the maintenance of gut barrier function [59]. Additionally, an increase in probiotic bacteria, such as Lactobacillus, is accompanied by a decrease in the concentration of pathogenic E. coli, in accordance with authors [60,61] who stated that Lactobacillus can quantitatively inhibit the adherence of pathogenic E. coli. The potential effect of phenolic compounds in CCE on the gut microbiota may result from modulation of the bacterial population by acting as prebiotics and enriching the beneficial bacteria [62]. The antimicrobial properties of polyphenols are of primary significance and inhibit biofilm formation in the gut by suppressing harmful bacteria [63]. In vitro testing of the antimicrobial activity of cornelian cherry extract demonstrated its inhibitory effects against Staphylococcus aureus and Escherichia coli [64]. Caffeic acid, present in CCE, has been described as a potential inhibitor of the growth of E. coli and Clostridium [65].

Furthermore, flavonoids can change the microbiota ecosystem through their bacteriostatic or bactericidal properties [66]. In addition, blueberry flavonoids can inhibit the activity of $E$. coli, which reduces the integrity of the intestinal barrier as a key mechanism of its pathogenesis [67]. Moreover, feeding with dietary polyphenol-rich grapes was shown to significantly increase the Lactobacillus population in the ceca of broiler chickens [4].

In the small intestine, glucose transporter 1 (GLUT1), recognized as part of solute carrier family 2 (SLC2A1), facilitates glucose transport across the apical surface of the 
enterocytes, whereas glucose and fructose transport across the basal side of the enterocytes and into the blood circulation is facilitated by GLUT2 [68]. In the current study, the inclusion of CCE in the broiler diet upregulated the expression of glucose nutrient transporters such as GLUT1, GLUT2, and SGLT-1, which are responsible for the transportation of fructose, galactose, mannose, and glucosamine. This can be attributed to the presence of anthocyanins in CCE that are characterized by $\alpha$-glucosidase inhibitor activity and the capacity to combine with and activate peroxisome proliferator-activated receptor gamma $(\operatorname{PPAR} \gamma)$ [69]. The activation of PPAR $\gamma$ accelerates lipid metabolism and glucose uptake by increasing the actions of insulin in glucose utilization in animals [70]. The enhanced expression of GLUT2 can regulate the digestion and absorption of poultry by modulating food consumption by controlling the feedback signal to the brain [71]. Additionally, cornelian cherry extract administration can initiate the uptake of glucose by tissues such as muscle and participate in increasing muscle mass in poultry [72,73]. Moreover, the upregulation of GLUT1 and GLUT2 can enhance their absorptive functions and increase the final body weight of broiler chickens via increasing nutrient transporter expression in the small intestine [74,75]. Additionally, plant-rich phenolics could promote the growth performance of broilers [41] through their potential to improve the antioxidant status of the gut [42]. Antioxidant capacity is a critical factor in poultry health that affects meat quality after slaughter. The radical scavenging ability is linked to the rich polyphenolic compound composition [76]. Animals have developed effective methods of protection against oxidative stress. SOD can eliminate superoxide anion free radicals, and GSH-PX and catalase can catalyze hydrogen peroxide decomposition [77]. Lipid peroxidation is produced by high levels of free radicals, and it leads to an increase in the content of MDA, the end product of lipid oxidation [78]. Levels of thiobarbituric acid reactive substance (MDA) are biomarkers for assessing the lipid peroxidation degree [79]. To the best of our knowledge, there are no data available on the impact of CCE supplementation on the expression of genes encoding the antioxidant enzymes in broilers. In the current study, the expression of antioxidant-related genes (SOD, GPX, and catalase) was upregulated in breast meat by increasing the CCE level. Chickens' breast meat that was not supplemented with CCE had elevated MDA levels and, as a result, lowered oxidative stability, compared with groups supplemented with CCE. Thus, dietary supplementation with CCE had a postmortem effect of decreasing the rate of lipid oxidation by decreasing the MDA content in breast meat, even after 90 days of storage. Similarly, the total antioxidant capacity and phenolic content in the broilers' breast meat improved following dietary supplementation with pomegranate peel extract [80]. Additionally, previous studies showed that lipid oxidation in chicken meat was reduced by feeding with dietary antioxidants, such as plant extracts rich in phenolic compounds [81,82]. A similar positive effect of dietary phenolic compounds on TBARS in breast meat was detected [83].

The higher antioxidant capacity of CCE may be related to the higher polyphenol and flavonoid contents [84], which augment the ability to scavenge radicals. Parallel results support the idea that lipid oxidation could be prevented by fortifying flavonoid antioxidants in animal feed [85]. Furthermore, supplementation of the broiler diet with blackcurrant-extract-rich-polyphenolic compounds enhanced the oxidative stability of their meat after 90 days of frozen storage [86].

Additionally, the reduced TBARS value was useful for lengthening the shelf time of meat products and improving the meat quality [11]. Additionally, the increased total phenolic content in the breast meat of broilers fed increased levels of CCE compared with broilers fed the control diet indicated a higher total antioxidant capacity [87], as these phenolic compounds are able to scavenger free radicals [88]. Besides this, supplementation with dietary CCE improved the DPPH scavenging activity of breast meat, especially at higher levels, even after 90 days of storage. The higher scavenging activity of DPPH indicated an increased antioxidant content in broiler meat, which has the potential to provide one proton to produce a stable DPPH2 compound, thus scavenging the free 
radicals [89]. Additionally, Cerit et al. [90] reported that cornelian cherry fruits have greater DPPH radical scavenging and ferric-reducing activity.

Moreover, the highest FRAP values were measured in meat enriched with higher levels of supplemental CCE. Faiz et al. [91] showed decreased TBARS values and better activity against 2,2-diphenyl-1-picrylhydrazyl (DPPH) free radicals, associated with a dosedependent increase in the total phenolic compound concentration detected in chickens meat after they received different levels of citrus waste. Furthermore, Jang et al. [92] stated that the oxidative stability of the breast meat of chickens fed a diet enriched with Coptis chinensis extract was mainly attributed to the higher concentration of polyphenolic compounds. The antioxidant content present in broiler meat tended to convert ferric ion $\left(\mathrm{Fe}^{3+}\right)$ to ferrous ion $\left(\mathrm{Fe}^{2+}\right)$ by providing one electron. Higher metal-chelating potential after supplementation with CCE protected tissues from damage resulting from oxidation. Similarly, a higher metal ion reducing capacity was observed in meat enriched with natural antioxidants in contrast with a control treatment group [93]. Similarly, cornelian cherry extract can reduce $20.41 \mu \mathrm{mol}$ of $\mathrm{Fe}^{2+} / \mathrm{g}$ of solution [13].

\section{Conclusions}

Supplementation with cornelian cherry extract, which is rich in antioxidants, improved the growth performance of broiler chickens via several mechanisms, such as increasing the favorable probiotic populations and lowering the concentration of harmful bacteria, such as E. coli spp. The modulation of genes expression responsible for glucose absorption and antioxidant enzymes indicates that CCE can play an effective role in the previously mentioned molecular mechanisms. CCE can scavenge free radicals, thereby improving the antioxidant capacity and lipid peroxidation of poultry meat without affecting its chemical composition. The results demonstrate that the application of dietary CCE $(200 \mathrm{mg} / \mathrm{kg})$ is recommended in chickens' diets to boost their growth performance, health, and meat shelf stability during long periods of frozen storage.

Author Contributions: Conceptualization, D.I., A.T.Y.K., A.M., A.S.M., K.A., F.E., V.T. and V.L.; methodology, D.I., A.T.Y.K., A.M., and K.A.; software, D.I., A.T.Y.K., A.S.M. A.M., M.A.N., F.E., K.A., V.T., and V.L.; validation, D.I., A.T.Y.K., A.M., and K.A., F.E.; formal analysis, D.I., A.T.Y.K., F.E., A.M., K.A., V.T. and V.L.; Investigation, D.I., A.T.Y.K., A.M., K.A., A.S.M., M.A.N., F.E., V.T., and V.L.; resources, D.I., A.T.Y.K., A.M., K.A., M.A.N., and F.E.; Data curation, D.I., A.T.Y.K., A.M., A.S.M., K.A., V.T., V.L., and F.E.; Writing-original draft preparation, D.I., A.T.Y.K., A.M., K.A., A.S.M., M.A.N., and F.E.; Writing - review and editing, D.I., A.T.Y.K., A.M., F.E., K.A., A.S.M., V.T., and V.L.; Visualization, D.I., A.T.Y.K., A.M., A.S.M., and K.A.; Supervision, D.I., A.T.Y.K., M.A.N., F.E., A.M., and K.A.; Funding acquisition, D.I., A.T.Y.K., A.M., M.A.N., F.E., A.S.M., and K.A. All authors have read and agreed to the published version of the manuscript.

Funding: This research received no external funding.

Institutional Review Board Statement: The management practices and procedures followed the ethical norms and guidelines of the Institutional Animal Care and Use Committee of the Faculty of Veterinary Medicine at Zagazig University (ZU-IACUC / 2020).

Data Availability Statement: The data source was sent to a section of nonpublished material.

Acknowledgments: The authors would like to acknowledge and thank Taif University research supporting project number (TURSP-2020/71), Taif University, Taif, Saudi Arabia.

Conflicts of Interest: The authors declare no conflict of interest.

\section{References}

1. Kurekci, C.; Al Jassim, R.; Hassan, E.; Bishop-Hurley, S.L.; Padmanabha, J.; McSweeney, C.S. Effects of feeding plant-derived agents on the colonization of Campylobacter jejuni in broiler chickens. Poult. Sci. 2014, 93, 2337-2346. [CrossRef] [PubMed]

2. Prakash, U.N.; Srinivasan, K. Beneficial influence of dietary spices on the ultrastructure and fluidity of the intestinal brush border in rats. Br. J. Nutr. 2010, 104, 31-39. [CrossRef] [PubMed]

3. Tiihonen, K.; Kettunen, H.; Bento, M.H.L.; Saarinen, M.; Lahtinen, S.; Ouwehand, A.; Schulze, H.; Rautonen, N. The effect of feeding essential oils on broiler performance and gut microbiota. Br. Poult. Sci. 2010, 51, 381-392. [CrossRef] [PubMed] 
4. Viveros, A.; Chamorro, S.; Pizarro, M.; Arija, I.; Centeno, C.; Brenes, A. Effects of dietary polyphenol-rich grape products on intestinal microflora and gut morphology in broiler chicks. Poult. Sci. 2011, 90, 566-578. [CrossRef]

5. Liu, H.; Liu, Y.; Hu, L.; Suo, Y.; Zhang, L.; Jin, F.; Feng, X.; Teng, N.; Li, Y. Effects of dietary supplementation of quercetin on performance, egg quality, cecal microflora populations, and antioxidant status in laying hens. Poult. Sci. 2014, 93, 347-353. [CrossRef]

6. Applegate, T.; Klose, V.; Steiner, T.; Ganner, A.; Schatzmayr, G. Probiotics and phytogenics for poultry: Myth or reality? J. Appl. Poult. Res. 2010, 19, 194-210. [CrossRef]

7. Kumar, P.; Patra, A. Beneficial uses of black cumin (Nigella sativa L.) seeds as a feed additive in poultry nutrition. Worlds Poult. Sci. J. 2017, 73, 872-885. [CrossRef]

8. Papuc, C.; Goran, G.V.; Predescu, C.N.; Nicorescu, V.; Stefan, G. Plant polyphenols as antioxidant and antibacterial agents for shelf-life extension of meat and meat products: Classification, structures, sources, and action mechanisms. Compr. Rev. Food Sci. Food Saf. 2017, 16, 1243-1268. [CrossRef]

9. Mehaisen, G.M.; Eshak, M.G.; Elkaiaty, A.M.; Atta, A.-R.M.; Mashaly, M.M.; Abass, A.O. Comprehensive growth performance, immune function, plasma biochemistry, gene expressions and cell death morphology responses to a daily corticosterone injection course in broiler chickens. PLoS ONE 2017, 12, e0172684. [CrossRef]

10. Akbarian, A.; Michiels, J.; Degroote, J.; Majdeddin, M.; Golian, A.; De Smet, S. Association between heat stress and oxidative stress in poultry; mitochondrial dysfunction and dietary interventions with phytochemicals. J. Anim. Sci. Biotechnol. $2016,7,37$. [CrossRef]

11. Jiang, J.; Xiong, Y.L. Natural antioxidants as food and feed additives to promote health benefits and quality of meat products: A review. Meat Sci. 2016, 120, 107-117. [CrossRef]

12. Tural, S.; Koca, I. Physico-chemical and antioxidant properties of cornelian cherry fruits (Cornus mas L.) grown in Turkey. Sci. Hortic. 2008, 116, 362-366. [CrossRef]

13. De Biaggi, M.; Donno, D.; Mellano, M.G.; Riondato, I.; Rakotoniaina, E.N.; Beccaro, G.L. Cornus mas (L.) fruit as a potential source of natural health-promoting compounds: Physico-chemical characterisation of bioactive components. Plant Foods Hum. Nutr. 2018, 73, 89-94. [CrossRef]

14. Do Nascimento, P.G.; Lemos, T.L.; Bizerra, A.; Arriaga, Â.; Ferreira, D.A.; Santiago, G.M.; Braz-Filho, R.; Costa, J.G.M. Antibacterial and antioxidant activities of ursolic acid and derivatives. Molecules 2014, 19, 1317-1327. [CrossRef]

15. Sarker, M.; Sharmin, M.; Huque, K.; Yang, C. Effect of Medicinal Plants and Probiotics on Thiobarbituric acid value in broiler chicken meat. In Proceedings of the 58th International Congress of Meat Science and Technology, Montreal, QC, Canada, 12-17 August 2012.

16. Quah, Y.; Lee, S.-J.; Lee, E.-B.; Birhanu, B.T.; Ali, M.; Abbas, M.A.; Boby, N.; Im, Z.-E.; Park, S.-C. Cornus officinalis Ethanolic Extract with Potential Anti-Allergic, Anti-Inflammatory, and Antioxidant Activities. Nutrients 2020, 12, 3317. [CrossRef]

17. Deng, S.; West, B.J.; Jensen, C.J. UPLC-TOF-MS characterization and identification of bioactive iridoids in Cornus mas fruit. J. Anal. Methods Chem. 2013, 2013. [CrossRef]

18. Krośniak, M.; Gąstoł, M.; Szałkowski, M.; Zagrodzki, P.; Derwisz, M. Cornelian cherry (Cornus mas L.) juices as a source of minerals in human diet. J. Toxicol. Env. Health A 2010, 73, 1155-1158. [CrossRef]

19. Dinda, B.; Kyriakopoulos, A.M.; Dinda, S.; Zoumpourlis, V.; Thomaidis, N.S.; Velegraki, A.; Markopoulos, C.; Dinda, M. Cornus mas L. (cornelian cherry), an important European and Asian traditional food and medicine: Ethnomedicine, phytochemistry and pharmacology for its commercial utilization in drug industry. J. Ethnopharmacol. 2016, 193, 670-690. [CrossRef]

20. Pawlowska, A.M.; Camangi, F.; Braca, A. Quali-quantitative analysis of flavonoids of Cornus mas L. (Cornaceae) fruits. Food Chem. 2010, 119, 1257-1261. [CrossRef]

21. Dzydzan, O.; Bila, I.; Kucharska, A.Z.; Brodyak, I.; Sybirna, N. Antidiabetic effects of extracts of red and yellow fruits of cornelian cherries (Cornus mas L.) on rats with streptozotocin-induced diabetes mellitus. Food Funct. 2019, 10, 6459-6472. [CrossRef]

22. Krisch, J. Effect of fruit juices and pomace extracts on the growth of Gram-positive and Gram-negative bacteria. Acta Biol. Szeged 2008, 52, 267-270.

23. Ersoy, N.; Bagci, Y.; Gok, V. Antioxidant properties of 12 cornelian cherry fruit types (Cornus mas L.) selected from Turkey. Sci. Res. Essays 2011, 6, 98-102.

24. Narimani-Rad, M.; Zendehdel, M.; Abbasi, M.M.; Abdollahi, B.; Lotfi, A. Cornelian cherry (Cornus mas L.) extract affects glycemic status in Wistar rats. Bull. Env. Pharm. Life Sci. 2013, 2, 48-50.

25. Waksmundzka-Hajnos, M.; Sherma, J. High Performance Liquid Chromatography in Phytochemical Analysis; CRC Press: Boca Raton, FL, USA, 2010.

26. Aziza, A.; Quezada, N.; Cherian, G. Antioxidative effect of dietary Camelina meal in fresh, stored, or cooked broiler chicken meat. Poult. Sci. 2010, 89, 2711-2718. [CrossRef] [PubMed]

27. Fotiadis, D.; Kanai, Y.; Palacín, M. The SLC3 and SLC7 families of amino acid transporters. Mol. Asp. Med. 2013, 34, 139-158. [CrossRef] [PubMed]

28. Bröer, S. Amino acid transport across mammalian intestinal and renal epithelia. Physiol. Rev. 2008, 88, 249-286. [CrossRef] [PubMed]

29. Mueckler, M.; Thorens, B. The SLC2 (GLUT) family of membrane transporters. Mol. Asp. Med. 2013, 34, 121-138. [CrossRef] [PubMed] 
30. Ruhnke, I.; Röhe, I.; Goodarzi Boroojeni, F.; Knorr, F.; Mader, A.; Hafeez, A.; Zentek, J. Feed supplemented with organic acids does not affect starch digestibility, nor intestinal absorptive or secretory function in broiler chickens. J. Anim. Physiol. Anim. Nutr. 2015, 99, 29-35. [CrossRef]

31. Aviagen, W. Ross 308: Broiler Nutrition Specification. Available online: https://tmea.aviagen.com/assets/Tech_Center/Ross_ Broiler/RossBroilerNutritionSpecs2019-EN.pdf (accessed on 30 September 2019).

32. AOAC. Official Methods of Analysis of AOAC International; Association of Official Analytical Chemists: Washington, DC, USA, 2012.

33. Short, F.; Gorton, P.; Wiseman, J.; Boorman, K. Determination of titanium dioxide added as an inert marker in chicken digestibility studies. Anim. Feed Sci. Technol. 1996, 59, 215-221. [CrossRef]

34. McDonald, P. Animal Nutrition; Pearson Education: London, UK, 2002.

35. Senevirathne, M.; Kim, S.-H.; Siriwardhana, N.; Ha, J.-H.; Lee, K.-W.; Jeon, Y.-J. Antioxidant potential of Ecklonia cava on reactive oxygen species scavenging, metal chelating, reducing power and lipid peroxidation inhibition. Food Sci. Technol. Int. 2006, 12, 27-38. [CrossRef]

36. Hwang, K.-E.; Choi, Y.-S.; Choi, S.-M.; Kim, H.-W.; Choi, J.-H.; Lee, M.-A.; Kim, C.-J. Antioxidant action of ganghwayakssuk (Artemisia princeps Pamp.) in combination with ascorbic acid to increase the shelf life in raw and deep fried chicken nuggets. Meat Sci. 2013, 95, 593-602. [CrossRef]

37. Oyaizu, M. Studies on product of browning reaction prepared from glucose amine. Jpn. J. Nutr. 1986, 44, 307-315. [CrossRef]

38. Zeb, A.; Ullah, F. A simple spectrophotometric method for the determination of thiobarbituric acid reactive substances in fried fast foods. J. Anal. Methods Chem. 2016. [CrossRef]

39. Livak, K.J.; Schmittgen, T.D. Analysis of relative gene expression data using real-time quantitative PCR and the $2-\Delta \Delta C T$ method. Methods 2001, 25, 402-408. [CrossRef]

40. Starčević, K.; Krstulović, L.; Brozić, D.; Maurić, M.; Stojević, Z.; Mikulec, Ž.; Bajić, M.; Mašek, T. Production performance, meat composition and oxidative susceptibility in broiler chicken fed with different phenolic compounds. J. Sci. Food Agric. 2015, 95, 1172-1178. [CrossRef]

41. Luo, J.; Song, J.; Liu, L.; Xue, B.; Tian, G.; Yang, Y. Effect of epigallocatechin gallate on growth performance and serum biochemical metabolites in heat-stressed broilers. Poult. Sci. 2018, 97, 599-606. [CrossRef]

42. Johannah, N.; Joseph, A.; Maliakel, B.; Krishnakumar, I. Dietary addition of a standardized extract of turmeric (TurmaFEED TM) improves growth performance and carcass quality of broilers. J. Anim. Sci. Technol. 2018, 60, 8.

43. El-Hack, A.; Mohamed, E.; Alagawany, M.; Abdel-Moneim, A.-M.E.; Mohammed, N.G.; Khafaga, A.F.; Bin-Jumah, M.; Othman, S.I.; Allam, A.A.; Elnesr, S.S. Cinnamon (Cinnamomum zeylanicum) Oil as a Potential Alternative to Antibiotics in Poultry. Antibiotics 2020, 9, 210. [CrossRef]

44. Erener, G.; Ocak, N.; Altop, A.; Cankaya, S.; Aksoy, H.M.; Ozturk, E. Growth performance, meat quality and caecal coliform bacteria count of broiler chicks fed diet with green tea extract. Asian-Australas. J. Anim. Sci. 2011, 24, 1128-1135. [CrossRef]

45. Herrero-Encinas, J.; Blanch, M.; Pastor, J.; Mereu, A.; Ipharraguerre, I.; Menoyo, D. Effects of a bioactive olive pomace extract from Olea europaea on growth performance, gut function, and intestinal microbiota in broiler chickens. Poult. Sci. 2020, 99, 2-10. [CrossRef]

46. Wang, M.; Suo, X.; Gu, J.; Zhang, W.; Fang, Q.; Wang, X. Influence of grape seed proanthocyanidin extract in broiler chickens: Effect on chicken coccidiosis and antioxidant status. Poult. Sci. 2008, 87, 2273-2280. [CrossRef] [PubMed]

47. Shakeri, M.; Cottrell, J.J.; Wilkinson, S.; Le, H.H.; Suleria, H.A.; Warner, R.D.; Dunshea, F.R. A Dietary Sugarcane-Derived Polyphenol Mix Reduces the Negative Effects of Cyclic Heat Exposure on Growth Performance, Blood Gas Status, and Meat Quality in Broiler Chickens. Animals 2020, 10, 1158. [CrossRef] [PubMed]

48. Johnson, M.H.; De Mejia, E.G. Phenolic compounds from fermented berry beverages modulated gene and protein expression to increase insulin secretion from pancreatic $\beta$-cells in vitro. J. Agric. Food Chem. 2016, 64, 2569-2581. [CrossRef] [PubMed]

49. Patra, A.K.; Amasheh, S.; Aschenbach, J.R. Modulation of gastrointestinal barrier and nutrient transport function in farm animals by natural plant bioactive compounds-A comprehensive review. Crit. Rev. Food Sci. Nutr. 2019, 59, 3237-3266. [CrossRef]

50. Ibrahim, D.; Sewid, A.H.; Arisha, A.H.; Abd El-Fattah, A.H.; Abdelaziz, A.M.; Al-Jabr, O.A.; Kishawy, A.T. Influence of Glycyrrhiza glabra Extract on Growth, Gene Expression of Gut Integrity, and Campylobacter jejuni Colonization in Broiler Chickens. Front. Vet. Sci. 2020, 7, 2063. [CrossRef]

51. Sarker, M.S.K.; Kim, G.M.; Sharmin, F.; Yang, C.J. Effects of medicinal plants, Alisma canaliculatum, Laminaria japonica and Cornus officinalis, treated with probiotics on growth performance, meat composition and internal organ development of broiler chicken. Asian J. Med. Biol. Res. 2016, 2, 696-702. [CrossRef]

52. Son, H.-K.; Kang, S.-T.; Lee, J.-J. Effects of Peucedanum japonicum Thunb. on lipid metabolism and antioxidative activities in rats fed a high-fat/high-cholesterol diet. J. Korean Soc. Food Sci. Nutr. 2014, 43, 641-649. [CrossRef]

53. Zhang, Y.; Chen, S.; Wei, C.; Chen, J.; Ye, X. Proanthocyanidins from Chinese bayberry (Myrica rubra Sieb. et Zucc.) leaves regulate lipid metabolism and glucose consumption by activating AMPK pathway in HepG2 cells. J. Funct. Foods 2017, $29,217-225$. [CrossRef]

54. Dykes, L.; Rooney, L.W. Sorghum and millet phenols and antioxidants. J. Cereal Sci. 2006, 44, 236-251. [CrossRef] 
55. Sozański, T.; Kucharska, A.; Szumny, A.; Magdalan, J.; Bielska, K.; Merwid-Ląd, A.; Woźniak, A.; Dzimira, S.; Piórecki, N.; Trocha, $\mathrm{M}$. The protective effect of the Cornus mas fruits (cornelian cherry) on hypertriglyceridemia and atherosclerosis through PPAR $\alpha$ activation in hypercholesterolemic rabbits. Phytomedicine 2014, 21, 1774-1784. [CrossRef]

56. Allison, R.W. Laboratory evaluation of plasma and serum proteins. In Thrall MA. Veterinary Hematology and Clinical Chemistry, 2nd ed.; Blackwell Publishing: London, UK, 2012; pp. 460-475.

57. Gopi, M.; Dutta, N.; Pattanaik, A.K.; Jadhav, S.E.; Madhupriya, V.; Tyagi, P.K.; Mohan, J. Effect of polyphenol extract on performance, serum biochemistry, skin pigmentation and carcass characteristics in broiler chickens fed with different cereal sources under hot-humid conditions. Saudi J. Biol. Sci. 2020, 27, 2719-2726. [CrossRef]

58. Williamson, G.; Kay, C.D.; Crozier, A. The bioavailability, transport, and bioactivity of dietary flavonoids: A review from a historical perspective. Compr. Rev. Food Sci. Food Saf. 2018, 17, 1054-1112. [CrossRef]

59. Bermudez-Brito, M.; Muñoz-Quezada, S.; Gomez-Llorente, C.; Matencio, E.; Bernal, M.J.; Romero, F.; Gil, A. Human intestinal dendritic cells decrease cytokine release against Salmonella infection in the presence of Lactobacillus paracasei upon TLR activation. PLoS ONE 2012, 7, e43197. [CrossRef]

60. Mack, D.R.; Michail, S.; Wei, S.; McDougall, L.; Hollingsworth, M.A. Probiotics inhibit enteropathogenic E. coli adherence in vitro by inducing intestinal mucin gene expression. Am. J. Physiol. Gastrointest. Liver Physiol. 1999, 276, G941-G950. [CrossRef]

61. Ibrahim, D.; Abdelfattah-Hassan, A.; Arisha, A.H.; Abd El-Aziz, R.M.; Sherief, W.R.; Adil, S.H.; El Sayed, R.; Metwally, A.E. Impact of feeding anaerobically fermented feed supplemented with acidifiers on its quality and growth performance, intestinal villi and enteric pathogens of mulard ducks. Livest. Sci. 2020, 242, 104299. [CrossRef]

62. Abbas, M.; Saeed, F.; Anjum, F.M.; Afzaal, M.; Tufail, T.; Bashir, M.S.; Ishtiaq, A.; Hussain, S.; Suleria, H.A.R. Natural polyphenols: An overview. Int. J. Food Prop. 2017, 20, 1689-1699. [CrossRef]

63. Espín, J.C.; González-Sarrías, A.; Tomás-Barberán, F.A. The gut microbiota: A key factor in the therapeutic effects of (poly)phenols. Biochem. Pharm. 2017, 139, 82-93. [CrossRef]

64. Savaş, E.; Tavşanlı, H.; Çatalkaya, G.; Çapanoğlu, E.; Tamer, C.E. The antimicrobial and antioxidant properties of garagurt: Traditional Cornelian cherry (Cornus mas) marmalade. Qual. Assur. Saf. Crop. Foods 2020, 12, 12-23. [CrossRef]

65. Cueva, C.; Moreno-Arribas, M.V.; Martín-Álvarez, P.J.; Bills, G.; Vicente, M.F.; Basilio, A.; Rivas, C.L.; Requena, T.; Rodríguez, J.M.; Bartolomé, B. Antimicrobial activity of phenolic acids against commensal, probiotic and pathogenic bacteria. Res. Microbiol. 2010, 161, 372-382. [CrossRef]

66. Etxeberria, U.; Fernández-Quintela, A.; Milagro, F.I.; Aguirre, L.; Martínez, J.A.; Portillo, M.P. Impact of polyphenols and polyphenol-rich dietary sources on gut microbiota composition. J. Agric. Food Chem. 2013, 61, 9517-9533. [CrossRef]

67. Polewski, M.A.; Esquivel-Alvarado, D.; Wedde, N.S.; Kruger, C.G.; Reed, J.D. Isolation and Characterization of Blueberry Polyphenolic Components and Their Effects on Gut Barrier Dysfunction. J. Agric. Food Chem. 2019, 68, 2940-2947. [CrossRef] [PubMed]

68. Williams, A.R.; Hansen, T.V.; Krych, L.; Ahmad, H.F.B.; Nielsen, D.S.; Skovgaard, K.; Thamsborg, S.M. Dietary cinnamaldehyde enhances acquisition of specific antibodies following helminth infection in pigs. Vet. Immunol. Immunopathol. 2017, 189, 43-52. [CrossRef] [PubMed]

69. Ruhnke, I.; Röhe, I.; Krämer, C.; Goodarzi Boroojeni, F.; Knorr, F.; Mader, A.; Schulze, E.; Hafeez, A.; Neumann, K.; Löwe, R. The effects of particle size, milling method, and thermal treatment of feed on performance, apparent ileal digestibility, and $\mathrm{pH}$ of the digesta in laying hens. Poult. Sci. 2015, 94, 692-699. [CrossRef] [PubMed]

70. Leonardini, A.; Laviola, L.; Perrini, S.; Natalicchio, A.; Giorgino, F. Cross-talk between PPAR and insulin signaling and modulation of insulin sensitivity. PPAR Res. 2009, 2009. [CrossRef]

71. Brubaker, P.L. The glucagon-like peptides: Pleiotropic regulators of nutrient homeostasis. Ann. N. Y. Acad. Sci. 2006, 1070, 10-26 [CrossRef]

72. Guo, X.; Sun, W.; Luo, G.; Wu, L.; Xu, G.; Hou, D.; Hou, Y.; Guo, X.; Mu, X.; Qin, L. Panax notoginseng saponins alleviate skeletal muscle insulin resistance by regulating the IRS 1-PI 3K-AKT signaling pathway and GLUT 4 expression. FEBS Open Bio 2019, 9, 1008-1019. [CrossRef]

73. Changxing, L.; Chenling, M.; Alagawany, M.; Jianhua, L.; Dongfang, D.; Gaichao, W.; Wenyin, Z.; Syed, S.; Arain, M.; Saeed, M. Health benefits and potential applications of anthocyanins in poultry feed industry. Worlds Poult. Sci. J. 2018, 74, 251-264. [CrossRef]

74. Hu, X.; Guo, Y.; Huang, B.; Bun, S.; Zhang, L.; Li, J.; Liu, D.; Long, F.; Yang, X.; Jiao, P. The effect of glucagon-like peptide 2 injection on performance, small intestinal morphology, and nutrient transporter expression of stressed broiler chickens. Poult. Sci. 2010, 89, 1967-1974. [CrossRef]

75. Al-Khalaifah, H.S.; Shahin, S.E.; Omar, A.E.; Mohammed, H.A.; Mahmoud, H.I.; Ibrahim, D. Effects of graded levels of microbial fermented or enzymatically treated dried brewer's grains on growth, digestive and nutrient transporter genes expression and cost effectiveness in broiler chickens. BMC Vet. Res. 2020, 16, 1-15. [CrossRef]

76. Czerwińska, M.E.; Melzig, M.F. Cornus mas and Cornus officinalis—Analogies and differences of two medicinal plants traditionally used. Front. Pharm. 2018, 9, 894. [CrossRef]

77. Crespo, I.; García-Mediavilla, M.V.; Almar, M.; González, P.; Tuñón, M.J.; Sánchez-Campos, S.; González-Gallego, J. Differential effects of dietary flavonoids on reactive oxygen and nitrogen species generation and changes in antioxidant enzyme expression induced by proinflammatory cytokines in Chang Liver cells. Food Chem. Toxicol. 2008, 46, 1555-1569. [CrossRef] 
78. Kim, J.E.; Clark, R.M.; Park, Y.; Lee, J.; Fernandez, M.L. Erratum: Lutein decreases oxidative stress and inflammation in liver and eyes of guinea pigs fed a hypercholesterolemic diet. Nutr. Res. Pr. 2013, 7, 146. [CrossRef]

79. Kotunia, A.; Wolinski, J.; Laubitz, D.; Jurkowska, M.; Rome, V.; Guilloteau, P.; Zabielski, R. Effect of sodium butyrate on the small intestine. J. Physiol. Pharm. 2004, 55, 59-68.

80. Saleh, H.; Golian, A.; Kermanshahi, H.; Mirakzehi, M.T. Effects of dietary $\alpha$-tocopherol acetate, pomegranate peel, and pomegranate peel extract on phenolic content, fatty acid composition, and meat quality of broiler chickens. J. Appl. Anim. Res. 2017, 45, 629-636. [CrossRef]

81. Hu, Z.; Wang, T.; Ahmad, H.; Zhang, J.; Zhang, L.; Zhong, X. Effects of different formulations of $\alpha$-tocopherol acetate (vitamin E) on growth performance, meat quality and antioxidant capacity in broiler chickens. Br. Poult. Sci. 2015, 56, 687-695. [CrossRef]

82. Akbarian, A.; Michiels, J.; Golian, A.; Buyse, J.; Wang, Y.; De Smet, S. Gene expression of heat shock protein 70 and antioxidant enzymes, oxidative status, and meat quality of cyclically heat challenged finishing broilers fed Oreganum compactum and Curcuma xanthorrhiza essential oils. Poult. Sci. 2014, 93, 1930-1941. [CrossRef]

83. Jung, S.; Choe, J.H.; Kim, B.; Yun, H.; Kruk, Z.A.; Jo, C. Effect of dietary mixture of gallic acid and linoleic acid on antioxidative potential and quality of breast meat from broilers. Meat Sci. 2010, 86, 520-526. [CrossRef]

84. Moldovan, B.; David, L. Influence of temperature and preserving agents on the stability of cornelian cherries anthocyanins. Molecules 2014, 19, 8177-8188. [CrossRef]

85. Zhong, R.; Tan, C.; Han, X.; Tang, S.; Tan, Z.; Zeng, B. Effect of dietary tea catechins supplementation in goats on the quality of meat kept under refrigeration. Small Rumin. Res. 2009, 87, 122-125. [CrossRef]

86. Sierżant, K.; Korzeniowska, M.; Król, B.; Orda, J.; Wojdyło, A. Oxidative stability of the meat of broilers fed diets supplemented with various levels of Blackcurrant extract (Ribes nigrum L.) during different time period. J. Chem. 2018, 2018. [CrossRef]

87. Moldovan, B.; Filip, A.; Clichici, S.; Suharoschi, R.; Bolfa, P.; David, L. Antioxidant activity of Cornelian cherry (Cornus mas L.) fruits extract and the in vivo evaluation of its anti-inflammatory effects. J. Funct. Foods 2016, 26, 77-87. [CrossRef]

88. Dave, R. In vitro models for antioxidant activity evaluation and some medicinal plants possessing antioxidant properties: An overview. Afr. J. Microbiol. Res. 2009, 3, 981-996.

89. Ibrahim, D.; Kishawy, A.T.; Khater, S.I.; Hamed Arisha, A.; Mohammed, H.A.; Abdelaziz, A.S.; El-Rahman, A.; Ghada, I.; Elabbasy, M.T. Effect of dietary modulation of selenium form and level on performance, tissue retention, quality of frozen stored meat and gene expression of antioxidant status in Ross broiler chickens. Animals 2019, 9, 342. [CrossRef] [PubMed]

90. Cerit, İ.; Şenkaya, S.; Tulukoğlu, B.; Kurtuluş, M.; Seçilmişoğlu, Ü.R.; Demirkol, O. Enrichment of functional properties of white chocolates with cornelian cherry, spinach and pollen powders. Gida J. Food 2016, 41, 311-316. [CrossRef]

91. Faiz, F.; Khan, M.I.; Butt, M.S.; Nawaz, H. Enhancement of broiler meat oxidative stability through dietary supplementation of citrus processing waste. Pak. J. Agric. Sci. 2017, 54, 893-898.

92. Jang, A.; Liu, X.-D.; Shin, M.-H.; Lee, B.-D.; Lee, S.-K.; Lee, J.-H.; Jo, C. Antioxidative potential of raw breast meat from broiler chicks fed a dietary medicinal herb extract mix. Poult. Sci. 2008, 87, 2382-2389. [CrossRef]

93. Banerjee, R.; Verma, A.K.; Das, A.K.; Rajkumar, V.; Shewalkar, A.; Narkhede, H. Antioxidant effects of broccoli powder extract in goat meat nuggets. Meat Sci. 2012, 91, 179-184. [CrossRef] 